\title{
Spatial distribution of soil shear-wave velocity and the fundamental period of vibration - a case study of the Saguenay region, Canada
}

Thomas Foulon, Ali Saeidi, Romain Chesnaux, Miroslav Nastev \& Alain Rouleau

To cite this article: Thomas Foulon, Ali Saeidi, Romain Chesnaux, Miroslav Nastev \& Alain Rouleau (2017): Spatial distribution of soil shear-wave velocity and the fundamental period of vibration - a case study of the Saguenay region, Canada, Georisk: Assessment and Management of Risk for Engineered Systems and Geohazards, DOI: 10.1080/17499518.2017.1376253

To link to this article: http://dx.doi.org/10.1080/17499518.2017.1376253

Published online: 20 Sep 2017.

Submit your article to this journal

View related articles

View Crossmark data $\nearrow$ 


\title{
Spatial distribution of soil shear-wave velocity and the fundamental period of vibration - a case study of the Saguenay region, Canada
}

\author{
Thomas Foulon $^{\mathrm{a}}$, Ali Saeidi ${ }^{\mathrm{a}}$, Romain Chesnaux ${ }^{\mathrm{a}}$, Miroslav Nastev ${ }^{\mathrm{b}}$ and Alain Rouleau ${ }^{\mathrm{a}}$

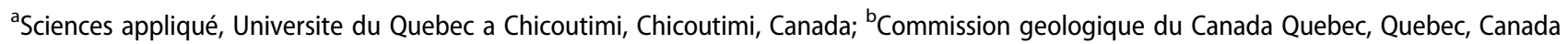

ABSTRACT

The spatial distribution of soil shear-wave velocity and the fundamental period of vibration were selected as input parameters for the determination of potential seismic site effects in the Saguenay region, Canada. The methodology used in this study involved three clear steps. First, a 3D geological model of the surficial deposits was built taking into consideration the type, spatial distribution and thickness of the deposits. Second, representative average $V_{s}$ values were determined for each of the major soil units. Finally, the average shear-wave velocity from the ground surface to bedrock $\left(V_{\text {sav }}\right)$, the shear-wave velocity of the upper $30 \mathrm{~m}\left(V_{\mathrm{s} 30}\right)$ and the fundamental site resonance period $\left(T_{0}\right)$ were calculated over a regular grid for the study area. The results include the spatial distribution of the fundamental site resonance period, the average shear-wave velocity in the first $30 \mathrm{~m}$ of the ground and the spatial distribution of National Building Code of Canada seismic soil classes for the Saguenay region.
ARTICLE HISTORY

Received 5 March 2017

Accepted 31 August 2017

KEYWORDS

Seismic hazard and risk; seismic site effects; $V_{\mathrm{s} 30} ; T_{0}$

\section{Introduction}

Local geological conditions have a major control on the intensity and frequency content of ground-shaking and on the spatial distribution of damage during strong earthquakes (Bard et al. 1988). Surficial soil deposits, having lower shear-wave velocities than bedrock, often tend to amplify and extend the duration of earthquakerelated motion. This occurs as seismic waves, which carry a specific amount of energy, slow down upon encountering a low-velocity soil medium. To compensate for the reduced propagation of velocity (while conserving the amount of energy), the amplitude of the seismic waves increases. The potential for soil amplification of seismic energy is commonly referred to as the seismic site effect. Recent building codes in Europe and the United States incorporate the determination of the potential of seismic site effects into their provisions (CEN 2004; ICC 2012). Seismic site effects are defined by amplification factors with respect to a soil classification system based on the average shear-wave velocity $\left(V_{\mathrm{s}}\right)$ of the top $30 \mathrm{~m}\left(V_{\mathrm{s} 30}\right)$ as introduced by Borcherdt (1994). The current National Building Code of Canada (NBCC) (IRCC 2015) adopts the same principle although includes the modifications brought by Finn and Wightman (2004).

Although $V_{\mathrm{s} 30}$ is a useful parameter for engineers, its use as the only indicating variable to characterise site response remains controversial. It is not always well correlated with the observed seismic amplification and, in certain cases, can be a poor proxy for estimating seismic site effects (Castellaro, Mulargia, and Rossi 2008; Ghofrani, Atkinson, and Goda 2013). The fundamental period of resonance, $T_{0}$, is therefore used as a complementary parameter to understand this complex phenomenon from both a theoretical and a practical perspective (Ghofrani, Atkinson, and Goda 2013; Braganza et al. 2016). Field data confirm that $T_{0}$ is equivalent to four times the shear-wave travel time from the bedrock to the ground surface in the vertical direction (Joyner, Warrick, and Fumal 1981; Kramer 1995; Boore 2003; Towhata 2014). The highest seismic amplification can be expected in the $T_{0}$ range, whereas lower amplification peaks occur at subsequent periods of resonance (harmonics).

Several urban-scale studies of the spatial distribution of $V_{\mathrm{s} 30}$ and/or $T_{0}$ have been conducted recently in Canada (Benjumea et al. 2008; Motazedian and Hunter 2008; Hunter et al. 2010; Leboeuf et al. 2013; Rosset, Bour-Belvaux, and Chouinard 2015). The common approach is to rely on relatively dense sets of geophysical (non-invasive surface seismic reflection and refraction techniques, downhole seismic surveys, landstreamer shear-wave reflection profiling, etc.), geotechnical (standard penetration and cone penetration tests (CPTs)) and

CONTACT Thomas Foulon thomas.foulon1@uqac.ca $B$ Sciences appliqué, Universite du Quebec a Chicoutimi, 555 boulevard de l'université, Chicoutimi, Canada G7H 2B1

(c) 2017 Informa UK Limited, trading as Taylor \& Francis Group 
geological (surficial geology, borehole logs) data to delineate those zones most susceptible to seismic site effects. However, for regions marked by a clustered or an insufficient number of $V_{\mathrm{s} 30}$ and $T_{0}$ data, it may be inadequate to only rely on sparse field data. In such cases, geological and geomorphological information are used as ancillary data to increase the confidence in the results. To this end, a geological model is built and typical values of shearwave velocities are assigned to assess the seismic soil class (Wills and Clahan 2006; Benjumea et al. 2008; Nastev et al. 2016a, 2016b). The purpose of the geological model is to define the type and the thickness of the shallow soil layers at a given location. Particularly in areas with complex geology, an accurate geological model is required to best represent the observed spatial heterogeneity and improve the mapping of $V_{\mathrm{s} 30}$ and $T_{0}$.

The main objective of this paper is to describe the methodology used for generating $V_{\mathrm{s} 30}$ and $T_{0}$ spatial distributions for the Saguenay region in eastern Canada. These maps were obtained using a combination of a 3D geological model and typical $V_{\mathrm{s}}$ values assigned to the major soil units. The major data sources were obtained from a database developed from a large-scale mapping project conducted in the Saguenay-Lac-SaintJean region of Quebec as part of the provincial "Groundwater Knowledge Acquisition Program" (Chesnaux et al. 2011; CERM-PACES 2013). The standard and CPT data were made available by the Quebec Ministry of Transport. These first evaluations of $V_{\mathrm{s} 30}$ and $T_{0}$ address the urgent needs of the City of Saguenay for mitigating potential seismic risks. Our study also represents a valid starting point for preparing regional seismic scenarios and risk assessments.

\section{Study area and geology}

The City of Saguenay, located in the Saguenay-LacSaint-Jean region in eastern Canada, covers an area of $1136 \mathrm{~km}^{2}$ and has a population of 147,100 (Figure 1). The city is divided into three main districts: Chicoutimi, Jonquière and La Baie, and includes several neighbourhoods including Shipshaw, Laterrière and Bagotville (Figure 1). The city lies in the southern part of the east-west trending Saguenay graben (Hébert and Lacoste 1998). Two physiographical units are encountered: the highlands of the Canadian Shield mainly located to the south and west of the region and the Saguenay lowlands in the central and the northern portions of the study area (Dion 1986). Elevations range between 200 and $400 \mathrm{~m}$ in the highlands and between 90 and $160 \mathrm{~m}$ in the lowlands.

Saguenay is situated within the Grenville geological province (Davidson 1998) of the Canadian Shield. Most of the geological bedrock is composed of crystalline
Precambrian rock consisting of three broad units: gneissic units, plutonic rocks with pyroxene and granitic rocks. In the north-eastern part, remnants of Ordovician limestone units are preserved on top of the crystalline bedrock.

The stratigraphy of the Quaternary deposits has been studied by several authors (Lasalle and Tremblay 1978; Dion 1986; Paradis et al. 1998). More recently, Daigneault et al. (2011) created a detailed surficial geological map of the study region (Figure 1). The shallow stratigraphy is characterised by a succession of continental and marine units deposited in the late Quaternary, specifically at the end of the Wisconsinan glaciation and in the early Holocene (Lasalle and Tremblay 1978). Quaternary sediments can be grouped into five major stratigraphic units (from the bedrock to the surface): till, glaciofluvial sand and gravel, fine post-glacial sediments (clay and silt), coarse post-glacial sediments (sand and gravel) and various post-glacial floodplain, organic and landslide sediments (Figure 1). The spatial distribution of these units is strongly affected by bedrock topography (Daigneault et al. 2011).

- Till covers most of the bedrock in the study region. In the lowlands, the till is overlain by the post-glacial clayey unit. In the lowlands, the till is continuous, grey, compact and calcareous with a predominance of sand (50-80\%) ranging in thickness from a few metres to a little more than $10 \mathrm{~m}$, particularly along the main rivers. In the highlands, the till unit is generally discontinuous, having a sand matrix and an average thickness of about $1 \mathrm{~m}$.

- Glaciofluvial gravel was deposited by glacial meltwater. These sediments are present along the escarpment separating the highlands and lowlands, known as the Laterrière-Bagotville corridor. Here, the buried bedrock valley is filled with glaciofluvial gravel material composed of stratified sand and gravel with numerous blocks. Its thickness may reach $35 \mathrm{~m}$.

- Fine post-glacial sediments (clay and silt) are related to the incursion of the Laflamme Sea that covered the Saguenay-Lac-Saint-Jean lowlands between 13,100 and 10,600 years BP (Bouchard, Dion, and Tavenas 1983). This is the thickest and the most widespread stratigraphic unit in the Saguenay Graben and can be found mainly at elevations below $168.5 \mathrm{~m}$ (Daigneault et al. 2011). Clay deposits are observed as two facies: massive clay and stratified clay and sand.

- Coarse post-glacial sediments consist of sand and gravel that are also related to the incursion of the Laflamme Sea. They were deposited mainly in the Saguenay lowlands. These deposits are shallow-water sediments resulting from the in situ reworking of 


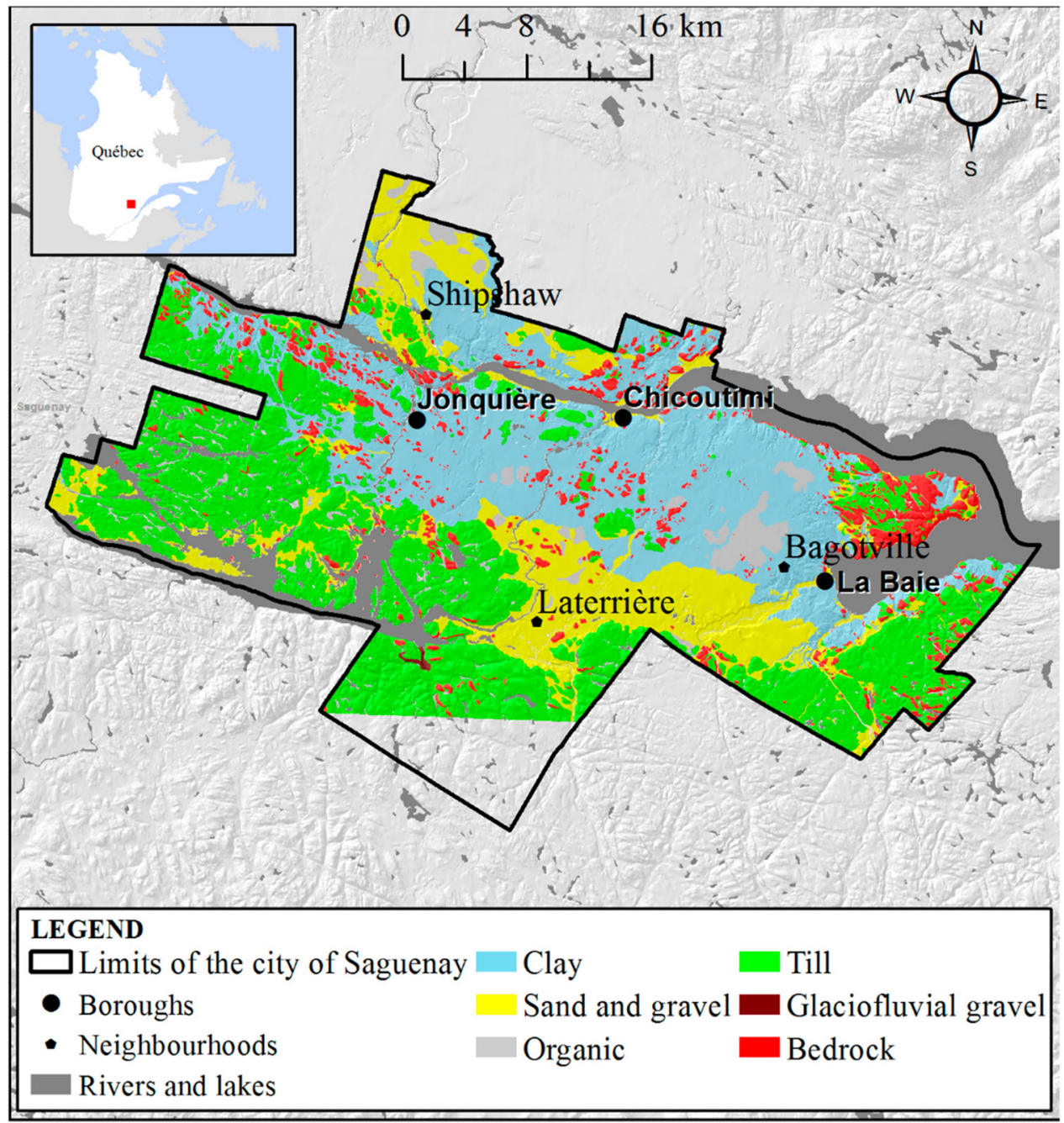

Figure 1. The City of Saguenay region with districts and neighbourhoods mentioned in the text. The background represents the simplified surficial geology map (modified from Daigneault et al. 2011)

the sediments and consisting of deltaic sand, reworked till, as well as reworked glaciofluvial and coastal sediments (Lasalle and Tremblay 1978).

- In addition to these four main units, which are most representative of the Quaternary stratigraphy, other sediments of limited extent can also be found in the region, including floodplain sediments, bog sediments and landslide deposits. Floodplain sediments are generally composed of silt, sand and gravel deposited in the valleys of the current rivers and have a maximum thickness of $3.5 \mathrm{~m}$ (Daigneault et al. 2011). Bog sediments, composed by fibrous peats, are found in proximity to La Baie, Chicoutimi, Laterrière and the north-eastern portion of the study area (Dion 1986). Landslide deposits are composed of reworked sand and reworked post-glacial clay. These deposits are principally present in the Shipshaw area, where a major landslide occurred in 1971 (Lasalle and Tremblay 1978).

\section{Construction of the 3D geological model}

The methodology used to map the spatial distribution of $V_{\mathrm{s} 30}$ and $T_{0}$ involves three principal steps. First, a 3D geological model of the surficial deposits is built taking into consideration the type, spatial distribution and thickness of the deposit. Second, representative average $V_{\mathrm{s}}$ values are determined for each of the major units. The $V_{\mathrm{s} 30}$ and $T_{0}$ values are then calculated over a regular, $250 \times 250 \mathrm{~m}$ grid to obtain the spatial distribution maps of these parameters. Below, we detail the procedure used to generate the 3D geological model (Figure 2), including the data collection and the steps for model development.

\subsection{Collected data}

The database developed by PACES (Chesnaux et al. 2011; CERM-PACES 2013) contains 3342 borehole logs distributed over the Saguenay territory. These logs 


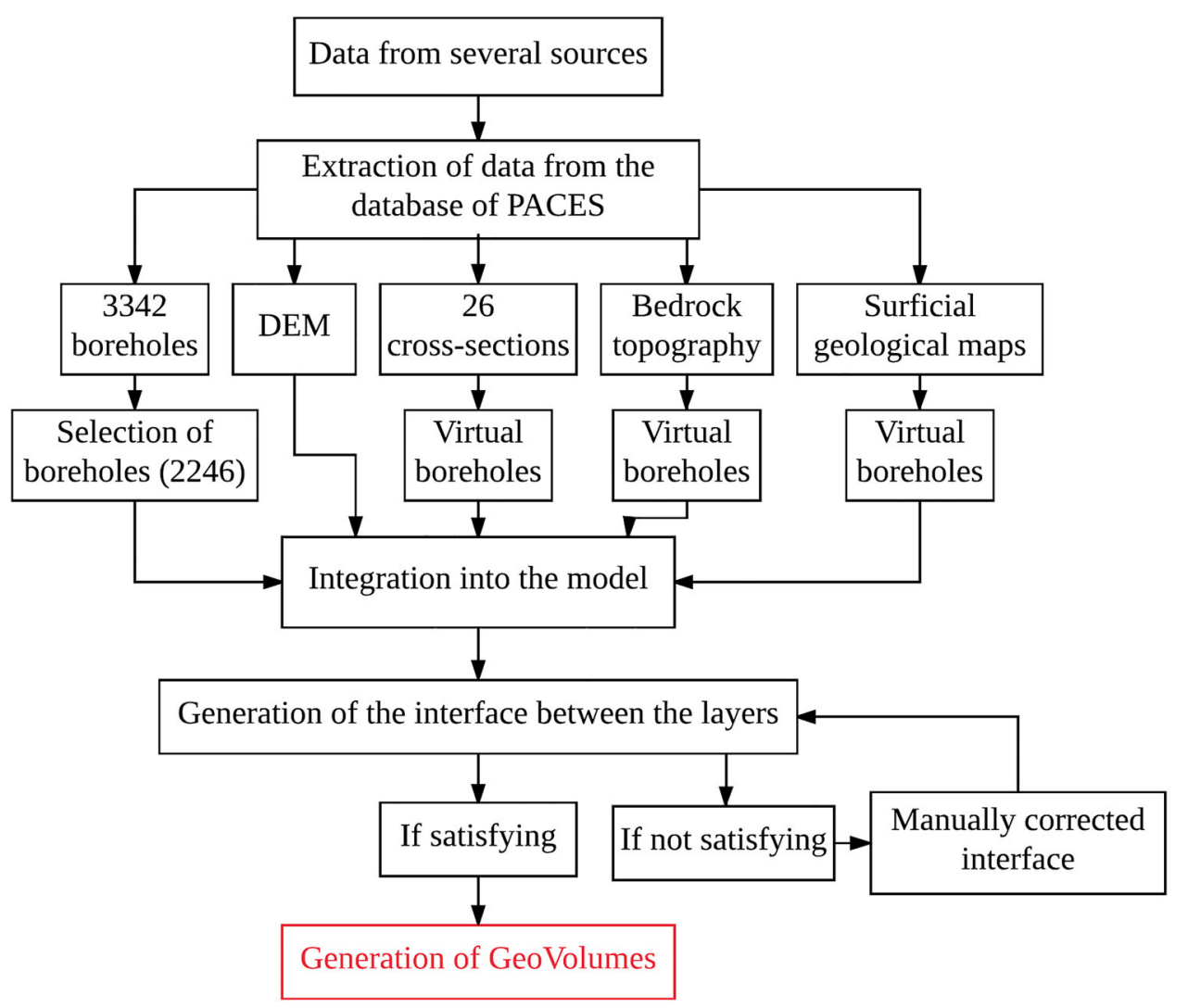

Figure 2. Flow chart detailing the procedure used to develop the 3D geological model used in this study.

originate from various sources and vary in terms of their quality (Figure 3). The application of a procedure to assess the degree of reliability, validate the data and identify of duplicates (CERM-PACES 2013) selected a subset of $2487 \operatorname{logs}$ to be considered in this study. The degree of reliability was determined by considering both the reliability of the location and the reliability of the source. The reliability of the location included uncertainty in terms of the digital coordinates or geo-referencing when the location was shown on a map. Source reliability included the source of information (e.g. whether it was descriptive, stratigraphic or technical) and the accessibility of the original reports. The next step involved data validation in terms of absence of conflicts with local hydrography (the localisation of the borehole is not in a river or a lake), the thickness of the stratigraphic layers (the sum of the thickness of the layers is the same that the depth reached by the borehole) and verifying that unit thickness and composition matches that of logs for nearby boreholes (within a radius of $600 \mathrm{~m}$ ). Duplicates were also systematically identified and deleted from the database. A pre-processing step has included a re-interpretation of the available textural descriptions into geological information. Among the available borehole logs, $12.9 \%$ provided only shallow information (depth $<5 \mathrm{~m}$ ), $60 \%$ reached up to $50 \mathrm{~m}$ in depth and $24 \%$ were at $50-100 \mathrm{~m}$ depth (Figure 3). From these boreholes, $75 \%$ reached the bedrock, providing valuable information for our model.

In addition, 26 stratigraphic cross-sections (Figure 3) were available from the recently completed hydrogeological map in the region (CERM-PACES 2013). These cross-sections were generated using available information from the database, including the digital elevation model (DEM), surface hydrography, geological maps, boreholes, rock outcrops and fractures (Chesnaux et al. 2011). These cross-sections integrate five broad geological units: sand, gravel, clay, till and rock.

The collected data were more concentrated along roads and in residential areas (Figure 3). Clusters of data were also observed in areas exposed to landslides. Elsewhere, data were sparse or non-existent requiring the interpretation of existing geological knowledge as a proxy for field measurements.

The stratigraphic information has been complemented, particularly for sectors having a low borehole density, by using the surficial geological map from Daigneault et al. (2011) and a recent model of the bedrock topography (CERM-PACES 2013; Chesnaux et al. 2017). The surficial geology map provided high-quality information to constrain the upper portion of the geological model and was particularly useful for representing the limits between 


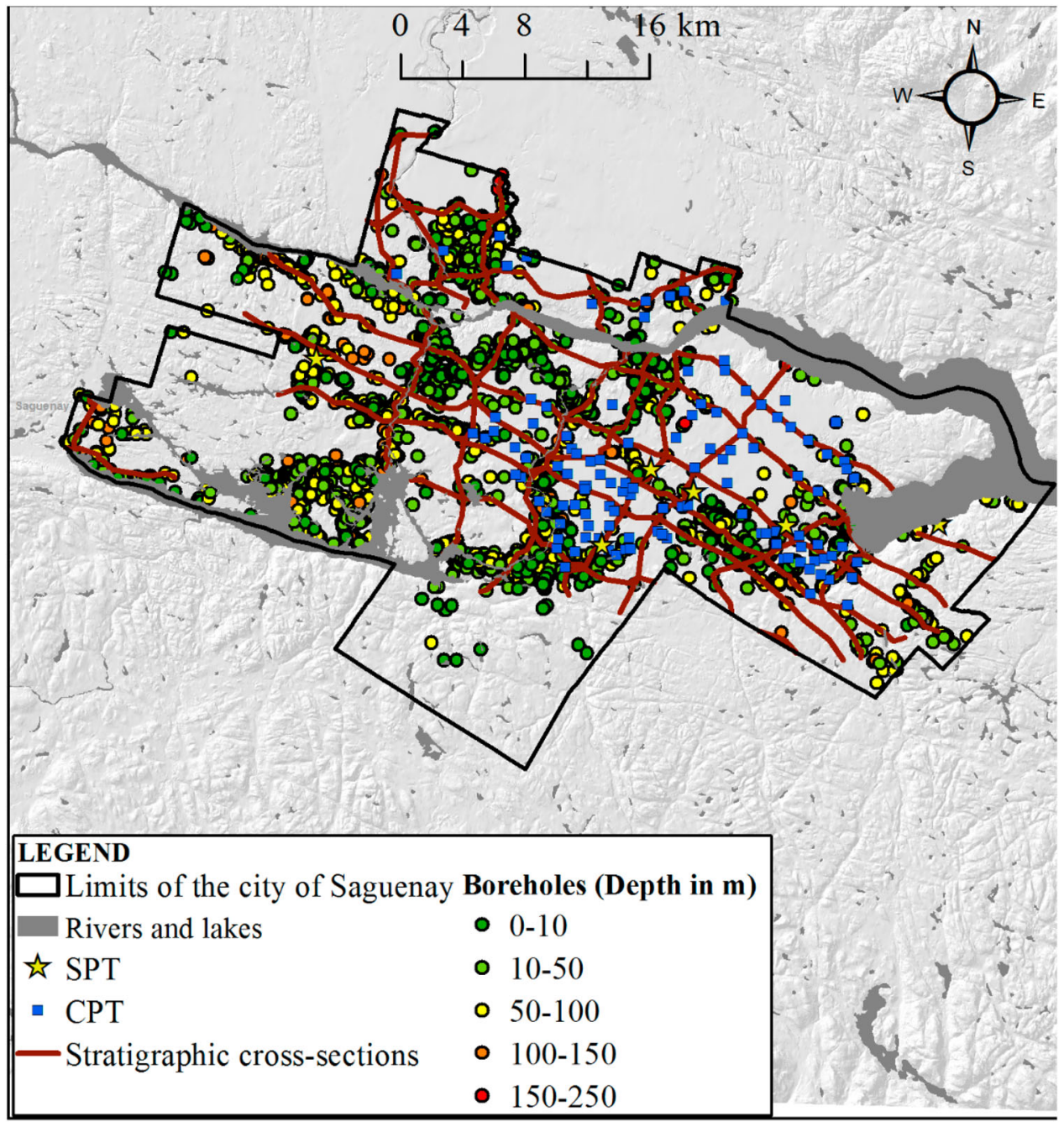

Figure 3. Spatial distribution of the borehole logs, CPTs, SPTs and stratigraphic cross-sections used in this study.

the layers at the surface and for modelling glacial till in the highlands based on the stratigraphic descriptions. The bedrock topography was generated following a rigorous protocol including comparative testing of three potential interpolation methods (Triangulated Irregular Network (TIN), Ordinary Kriging and Inverse Distance Weighting) each with their own specific functions and related parameters. Only a portion of the field data was used in these tests. The remaining field observations were used to validate the tested interpolation method (CERMPACES 2013; Chesnaux et al. 2017). In addition, the available dataset was complemented by "virtual boreholes" (i.e. control points) spaced at 500-m intervals along each stratigraphic section, which integrate the regional geology so as to constrain the model in areas having a low data density. The TIN interpolation method was, by far, the most accurate approach for representing the complex bedrock topography. The final model was in complete agreement with approximately $72 \%$ of the remaining part of field data.

\subsection{Model boundaries}

The topography of the terrain defines the upper boundary of the model. A DEM scale $(1: 20,000)$ was extracted from the Quebec topographic database of the Ministry of Energy and Natural Resources (MERN 2017). Its hypsometric precision is ca. $2 \mathrm{~m}$.

The bottom boundary of the model corresponds to the topography of the bedrock, which is locally complex (Hébert and Lacoste 1998). This complexity was simplified by using the model of the bedrock surface (CERMPACES 2013; Chesnaux et al. 2017) as described above.

\subsection{Regrouping of the geologic units}

All lithologic descriptions present in the database were grouped into five geologic units, namely (from bottom to the top) till, glaciofluvial gravel, post-glacial clay, sand and gravel. Each of these main units covers a large portion of the study area and represents a known 
sequence of geological events. The glaciofluvial gravel was considered separately from the other coarse sediments because of its lower position in the vertical stratigraphy (higher compaction) and the particular depositional processes preceding the incursion of the Laflamme Sea. The upper sand and gravel unit in the model is composed of different types of gravel including the Laflamme Sea gravel, floodplain gravel and a portion of the outcropping glaciofluvial gravel. In the model, the "clay layer" contains all the post-glacial sediments having a predominantly fine matrix (silt and clay), whereas the sand unit represents the Laflamme Sea sand, floodplain sand and reworked sand.

\subsection{Modelling procedure}

Leapfrog Geo (ARANZ Geo Limited 2014) software was used for modelling the stratigraphy. This software uses an implicit modelling method that reduces data manipulation, applying polylines - segments that define the sedimentary interfaces - and polygons that represent the sedimentary interfaces interpolated from the polylines. In contrast to explicit models, where the geological structures are drawn based directly on the input data, the implicit modelling technique applies specifically developed mathematical algorithms to generate the different structures and their contacts. The software applies the projection of the user-provided DEM and imposes the use of a single projection system over the entire model. Therefore, the coordinates of all the data used for the modelling were first unified to the North American 1983 (NAD 83) Transverse Mercator projection system. Polygons representing the sedimentary interfaces were interpolated from both information obtained from the field and virtual (knowledge driven) data integrated into the model. In both cases, this information was entered as either points (boreholes) or polylines (crosssections, maps). The modelled interfaces were corrected by manually drawing polylines and adding additional virtual data to further constrain the model. The model was run again with this reinterpreted information to refine the polygons. Once the obtained sedimentary interfaces had an accuracy deemed to be satisfactory, the software automatically generated GeoVolumes by filling the voids between the sedimentary interfaces. These GeoVolumes are the 3D features representing volumes of each stratigraphic layer.

Many assumptions and approximations are required to develop a stratigraphy that represents the geological history of the region and to model sectors having sparse data coverage. The modelling process started with the determination of the upper boundary (DEM combined with the map of the surficial sediments) and the lower boundary (bedrock surface). Next, the upper and the lower surfaces of the clay unit were modelled, as this was the major unit in the lowlands. The till unit was then simulated as a continuous layer between the clay unit and the bedrock, with a maximum thickness of 10 $\mathrm{m}$ in the lowlands (Dion 1986). In the highlands, where field data coverage is minimal, the till layer was modelled as discontinuous and as having an average thickness of $1 \mathrm{~m}$ (Daigneault et al. 2011). The gravel layer was distributed locally on top of the clay unit. Likewise, the sand layer was placed on top of the clay or gravel unit. In both cases, the surficial map was used to limit the extent of these coarse units.

The glaciofluvial gravel provided a major modelling challenge as its boundaries are poorly known and the number of boreholes that penetrate this unit is insufficient to provide a good characterisation (CERMPACES 2013). In the Laterrière-Bagotville corridor, this unit presumably lies between the till and the clay layers. The limits of this unit were defined using several borehole data, the simplified contours established by Lasalle and Tremblay (1978) and existing knowledge related to the deposition of the glaciofluvial deposits. The latter was particularly important as a substitute for the scarce information on the form and the thickness of the glaciofluvial gravel layer. The extent of this unit was inferred from the limits of the buried valley as observed from the bedrock topography in the Laterrière-Bagotville corridor, with a greater thickness assigned to the bedrock valley basins and thinner deposits along the upper portion of the bedrock between the basins.

Another challenge was the sector of Shipshaw, which represents a complex stratigraphy due to the presence of sediments reworked by several landslides. Two crosssections constructed by Lasalle and Tremblay (1978) show a sequence of alternating clayey and sandy sediments. Under such conditions, it became obvious that a realistic stratigraphy of the ancient landslide site was too complex at the local scale to be integrated into the present model. Therefore, we ignored sequences that were less than 3-m thick and that were not consistent with the regional stratigraphy. For example, we would ignore two 1-m-thick clay layers found within a 20 -m-thick sand layer, retaining only the sand component. The authors acknowledge that such simplification may result in significant uncertainty for the corresponding $V_{\mathrm{s}}$ values, possibly over- or under-estimating field conditions.

\subsection{D model}

The spatial distribution of each layer, the total thickness of the deposits calculated as the sum of the individual 
thicknesses of the five Quaternary units and two major cross-sections are presented in Figures 4 and 5, respectively.

A major characteristic of the model was the presence of a discontinuous and thin till layer that alternated with rock outcrops in the highlands (Figure 4(e)). Above this layer, some discontinuous fluvioglacial gravel and sand deposits were observed over part of the area (Figure 4 (d)). The thickness of the sediments ranged up to 3 $\mathrm{m}$. The thickest deposits were observed in the Shipshaw area, in the Laterrière-Bagotville corridor and locally in the central portion of the lowlands (Figure 4(f)). The clay layer was predominant in the stratigraphic sequence reaching up to $80 \mathrm{~m}$ in thickness (Figure $4(\mathrm{c})$ ) in the lowlands, where only a few bedrock outcrops can be observed. Coarse sediments (sand and gravel) were present to the north and the south where vast $10-20-\mathrm{m}$ thick blankets of these sediments were observed along the escarpment separating the lowlands from the highlands (Figure 4(a,b)). The fluvioglacial deposit layer, situated along the Laterrière-Bagotville corridor, ranged in thickness between 10 and $30 \mathrm{~m}$ with a maximum thickness of $43 \mathrm{~m}$.

The A- $\mathrm{A}^{\prime}$ cross-section (Figure 5), oriented W-NW/ E-SE, overlaps the highlands at its two extremities and crosses the lowlands through its central portion. A thin, 1-m-thick, discontinuous till layer is observed in the highlands. The lowlands are characterised by a very thick deposit of clay in the bedrock depressions. The B-B' cross-section, oriented N-NW/S-SE, crosses the lowlands over a $30-\mathrm{km}$ length to the NW and the highlands to the SE. The first $9 \mathrm{~km}$, in the Shipshaw area, show a very thick deposit of sand and clay. In the middle of this cross-section, the thickness of the approximately horizontal clay unit depends on the bedrock topography. The highlands are covered with a thin discontinuous till layer, locally overlaid by fluvioglacial granular sediments (gravel and sand).

\section{Shear-wave velocity values}

After defining the spatial distribution of the type and thickness of the deposits, representative average values of $V_{\mathrm{s}}$ were assessed and assigned to each stratigraphic unit to define the spatial distribution of $V_{\mathrm{s} 30}$ and $T_{0}$. The results of 64 standard penetration tests (SPTs) and 122 CPTs were obtained from the Quebec Ministry of Transport (Figure 3). The 64 SPTs were conducted at different depths in 6 boreholes. Several empirical relationships have been proposed in the literature to estimate the shear-wave velocities from these tests (Ohta and Goto 1978; Hegazy and Mayne 1995; Mayne and Rix 1995; Robertson 2009).
Analyses of the sediment type, deposition mechanism and origin were undertaken to determine the most appropriate of these empirical relationships. For the CPT data, a pre-treatment removed intervals that were not associated with the clay. Then, the empirical relationships of Mayne and Rix (1995) were selected for estimating $V_{\mathrm{s}}$ given that they were derived from Canadian sites having clays that were deposited under glaciomarine conditions, this also being the case for our study area.

The $V_{\text {s }}$ values decreased considerably over the first 5 $\mathrm{m}$ from the surface (Figure 6(a)). This phenomenon is a result of the desiccation and freeze-thaw processes in the surficial layer, or due to the artificial over-consolidation along roads as the preferred location for testing (Hunter et al. 2010). Below $5 \mathrm{~m}$, the $V_{\mathrm{s}}$ values increased with depth. The average range of $V_{\mathrm{s}}$ values was between 80 and $250 \mathrm{~m} / \mathrm{s}$.

For the SPTs, we selected the empirical relationship for medium sand by Ohta and Goto (1978), as medium-sized sand is dominant in the study area (Dion 1986). The profile of shear-wave velocity interpreted for the sand (Figure 6(b)) showed that $V_{\mathrm{s}}$ increased from 80 to $260 \mathrm{~m} / \mathrm{s}$ with depth.

Typical $V_{\mathrm{s}}$-depth relationships were determined by applying a simple regression analysis; the regression equations are presented in Figure 6(a,b). As expected, the sandy soils displayed a higher $V_{s}$ (Maugeri and Soccodato 2014) than clays (Figure 6(a,b)). Both units showed significant scatter in their shear-wave velocity values. This scatter resulted from either variability of grain-size distribution and compaction or due to the greater uncertainties introduced by the geotechnical data. A comparison can be made with $V_{\mathrm{s}}$-depth relationships for similar soil types in the St. Lawrence Lowlands (Figure 7) using results presented by Nastev et al. (2016b). The relationships for the clay have a similar shape in both areas, but with average values about 10 $\mathrm{m} / \mathrm{s}$ lower in the present study for equal depths. The similar shape is consistent given the same origins and glaciomarine deposition mechanisms for both sites. However, it seems that the erosional processes in Saguenay, where an average of $10-15 \mathrm{~m}$ of sediments were eroded (Dion 1986), were less active than in the St. Lawrence Lowlands. This difference in the erosional processes results in less compacted clays in the Saguenay and explains the lower value of $V_{\mathrm{s}}$ (Dobry and Vucetic 1987). The $V_{\mathrm{s}}$-depth relationships for sandy soils have a similar shape as well, but the $V_{\mathrm{s}}$ values of the present study are considerably lower, $50 \mathrm{~m} / \mathrm{s}$ lower on average at equal depth. However, this difference for the sand layer is lower than the standard deviation $(\sigma)$ of the $V_{\mathrm{s}}(52.4 \mathrm{~m} / \mathrm{s}$ for Nastev et al. [2016a, 2016b] and $29.83 \mathrm{~m} / \mathrm{s}$ for our study). This difference between the 

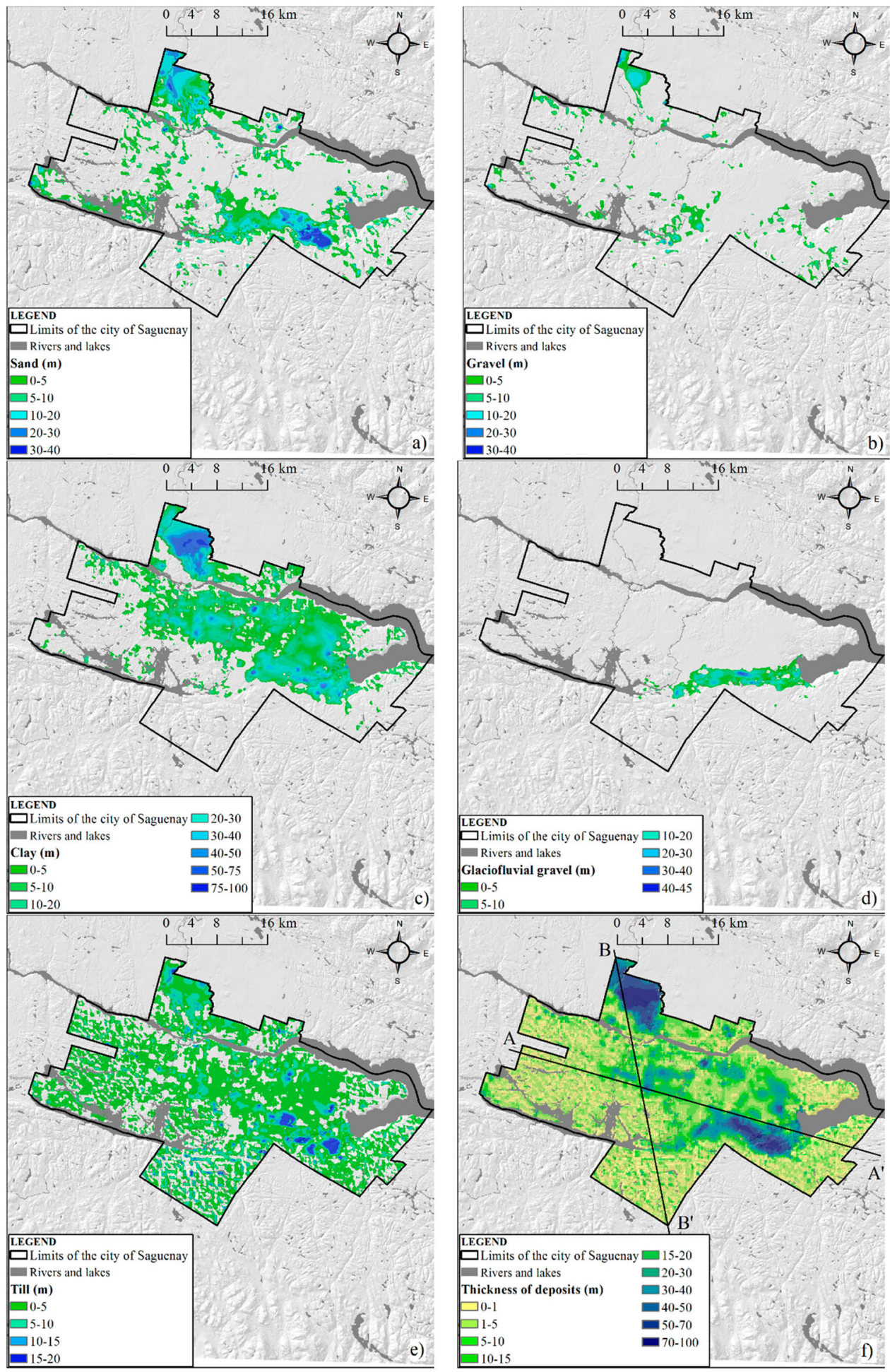

Figure 4. Spatial distribution of (a) sand; (b) gravel; (c) clay; (d) glaciofluvial gravel and (e) till. (f) Thickness of deposits, lines indicate the position of the cross-sections in Figure 5.

relationships can be due to the specific characteristics of the sand in our study.

The $V_{\mathrm{s}}$-depth relationship of the sand layer was considered as a good approximation of the average $V_{s}$ for both granular sediments (sand and gravel). Although gravels exhibit slightly higher $V_{s}$ values than sand layers
(Wair, DeJong, and Shantz 2012), the possible difference is expected to have only a weak influence on the final $V_{\mathrm{s} 30}$ and $T_{0}$ as the gravel layer covers a much smaller area. Concerning the till unit and the bedrock, no $V_{\mathrm{s}}$ data could be obtained for the study area. Therefore, a representative value of $385 \mathrm{~m} / \mathrm{s}$ was applied to the till as 
Scale: 1:220 000

Vertical exaggeration: $50 x$

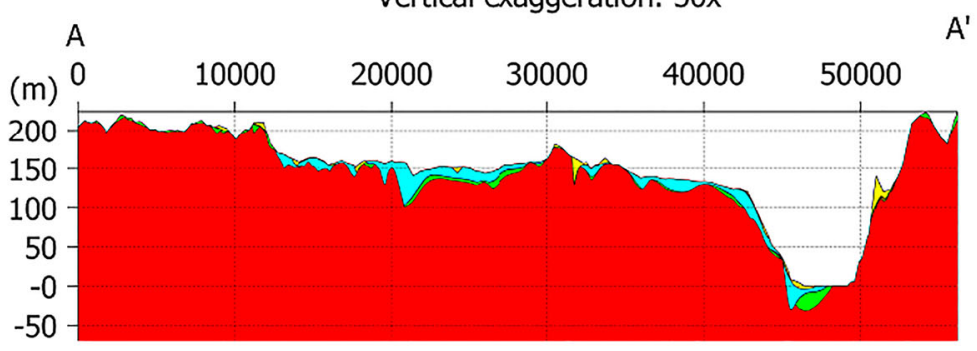

Scale: 1:210 000

Vertical exaggeration: $50 x$

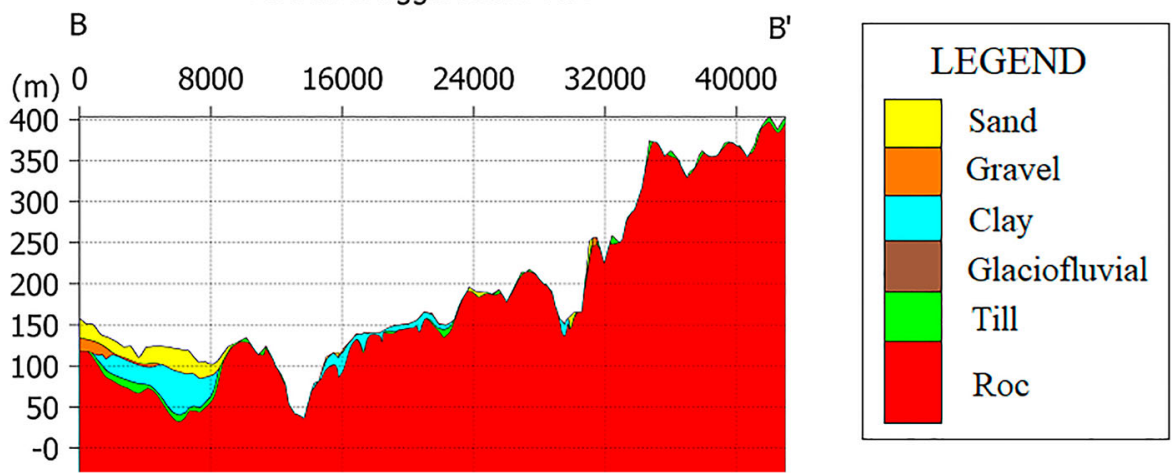

Figure 5. Stratigraphic cross-sections from those indicated in Figure 4(f). The scale is in metres.
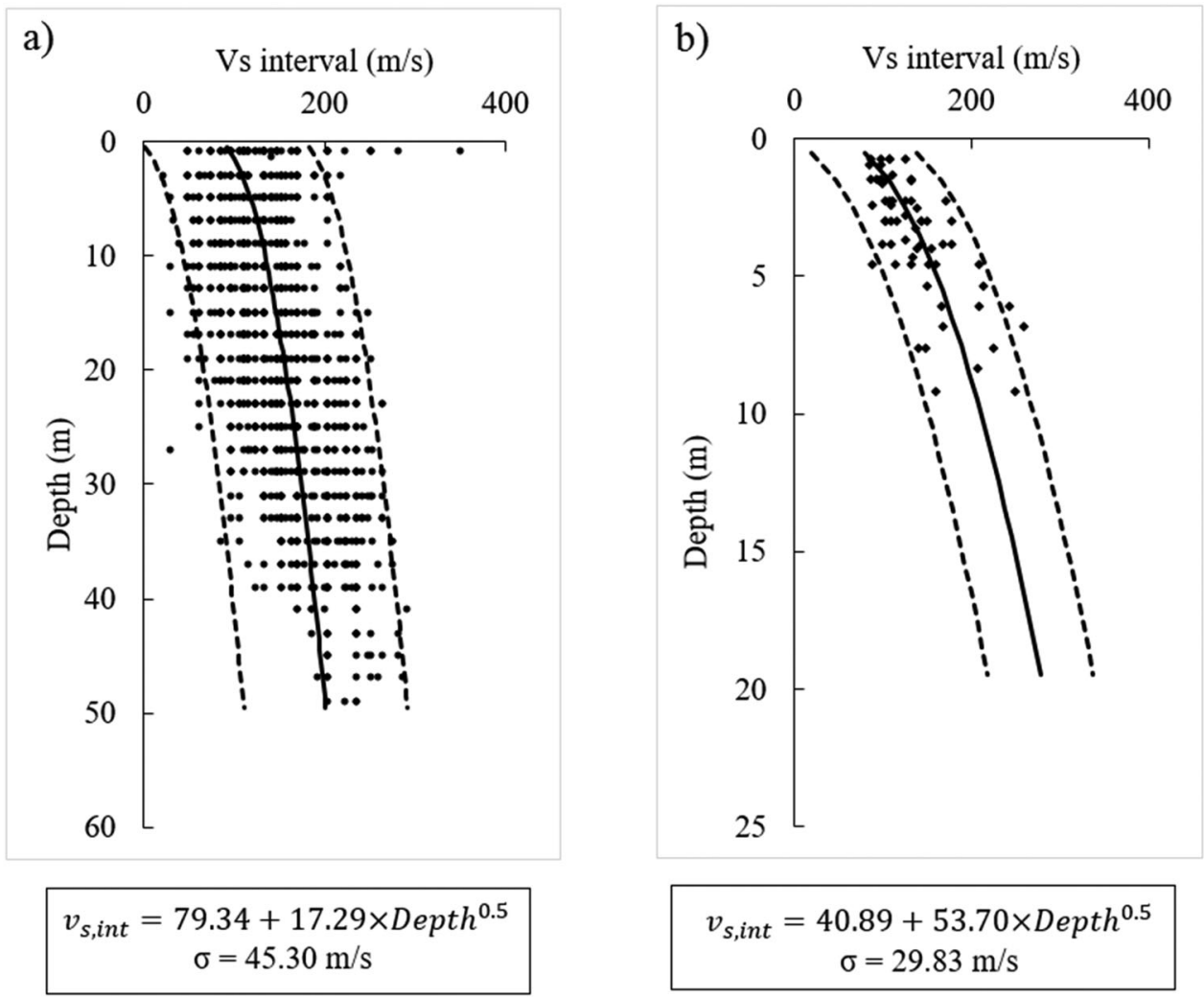

Figure 6. Interval shear-wave velocity vs. depth relationship for (a) clays and (b) sandy soils. Bold lines indicate average values; dashed lines indicate \pm 2 standard deviations $(\sigma)$. 


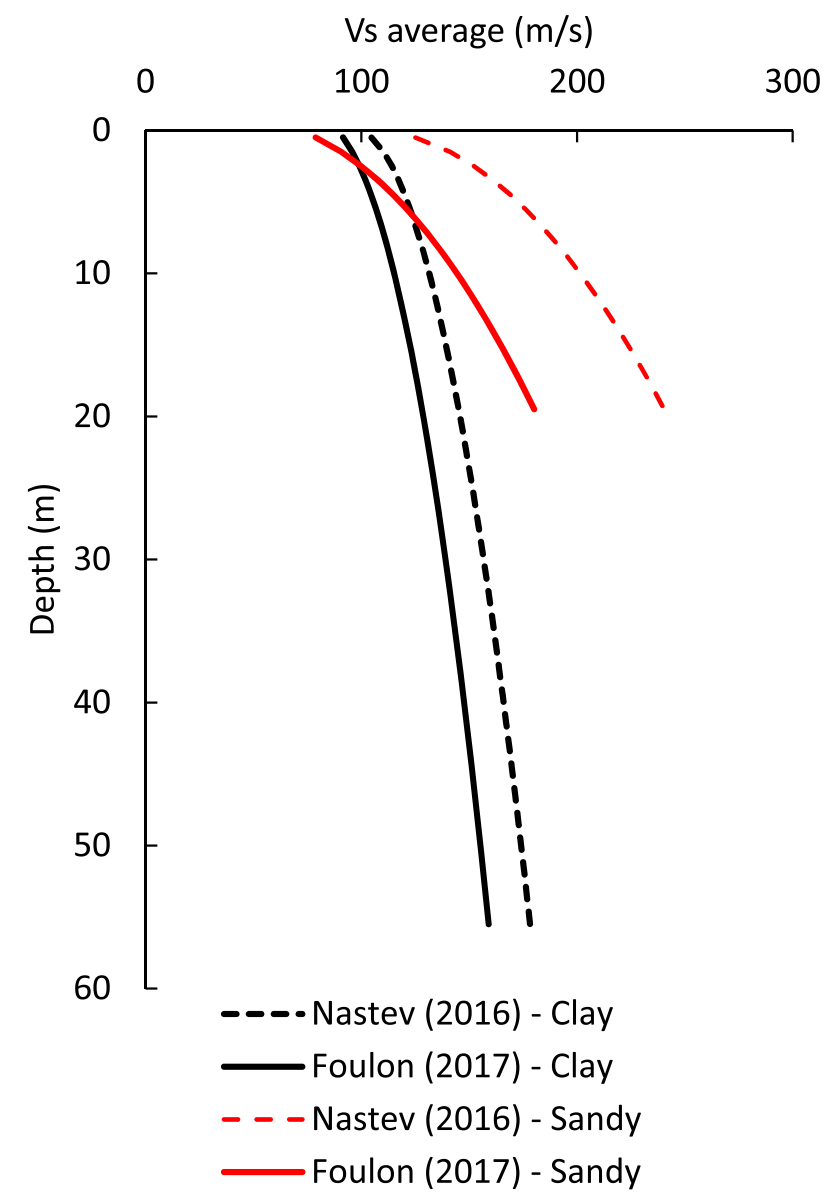

Figure 7. Average shear-wave velocity vs. depth relationship for clay and sandy soils of Nastev et al. (2016a, 2016b) and this study.

proposed by Nastev et al. (2016a) for the St. Lawrence Valley, geographically close to the Saguenay region and having similar depositional processes. The same was done for bedrock $V_{\mathrm{s}}=2500 \mathrm{~m} / \mathrm{s}$ for the Grenville geological province as it extends in both regions.

\section{Mapping of $V_{\mathrm{s} 30}$ and $T_{0}$}

The mapping of $V_{\mathrm{s} 30}$ and $T_{0}$ was made using the $3 \mathrm{D}$ geological model of surficial deposits and the typical values of shear-wave velocity assigned to each unit. First, the type of deposit, including the related values of thickness and depth were extracted from the 3D geological model for each cell of the raster $(250 \times 250 \mathrm{~m})$. Then the average $V_{\mathrm{s}}$ of each geological unit in the cell was determined using the representative values assumed in this study. The $V_{\mathrm{s} 30}$ value for each cell was calculated using the equation:

$$
V_{\mathrm{s} 30}=\frac{30}{\sum d_{n} / V_{\mathrm{s} n}}
$$

where $d_{n}$ is the thickness of the $n$th geological unit in the first $30 \mathrm{~m}$ of soil and $V_{s n}$ is the $V_{\mathrm{s}}$ value of the respective interval.
Likewise, the average $V_{\mathrm{s}}$ from the surface to bedrock $\left(V_{\text {sav }}\right)$ was obtained applying:

$$
V_{\mathrm{sav}}=\frac{d}{\sum d_{n} / V_{\mathrm{s} n}},
$$

where $d$ is the total deposit thickness, $d_{n}$ is the thickness of the $n$th sedimentary layer and $V_{s n}$ is the $V_{s}$ value in the $n$th sedimentary unit in the cell. This allows the calculation of $T_{0}$ as follows:

$$
T_{0}=\frac{4 d}{V_{\mathrm{sav}}} .
$$

The spatial distribution of $V_{\mathrm{sav}}, T_{0}, V_{\mathrm{s} 30}$ and the generated seismic soil classes are presented in Figure 8.

The lowest $V_{\mathrm{s}}$ values and the longest $T_{0}$ are characteristic of the thickest deposits found in the lowlands of Saguenay, particularly in the Shipshaw area, in the Laterrière-Bagotville corridor and near Jonquière and Chicoutimi (Figure $8(\mathrm{a}-\mathrm{d})$ ). The highest $V_{\mathrm{s}}$ and shortest $T_{0}$ values, on the other hand, are associated with the shallow till layer and rock outcrops located in the highlands. As well, transitional $V_{\mathrm{s} 30}$ zones can be observed between the low $V_{\mathrm{s}}$ sedimentary basin and high $V_{\mathrm{s}}$ rock outcrops present in the Shipshaw area and along the escarpment separating the lowlands from the highlands. These zones can be particularly affected by other seismic site effects such as the basin edge effect or seismic wave focusing influenced by the shape of the basins and by the gradual thinning of the surficial sediment.

\section{Discussion and conclusion}

The combination of the spatial distribution of $V_{\mathrm{s} 30}$ and $T_{0}$ as developed in this study provides a good understanding of the potential seismic site effects in the territory of the City of Saguenay.

The development of the 3D geological model and the relationships of the shear-wave velocity vs. depth were based on a relatively rich database of field measurements. However, the quality, the reliability and the distribution of these data across the study area were variable. An increase in data density and a better spatial distribution would improve our geological model. Sectors of former landslides also limit this model. The stratigraphy in these sectors can be locally very complex due to sediment reworking. The 3D geological model, as such, represents a simplification of the stratigraphy of the former landslides. However, the total thickness of deposits and the thickness of the till layer are not impacted by this simplification. The representative values of $V_{\mathrm{s}}$ were determined either from the interpretation of penetration test data (clay layer and granular sediments layer) or from relationships published in the literature for the till and 

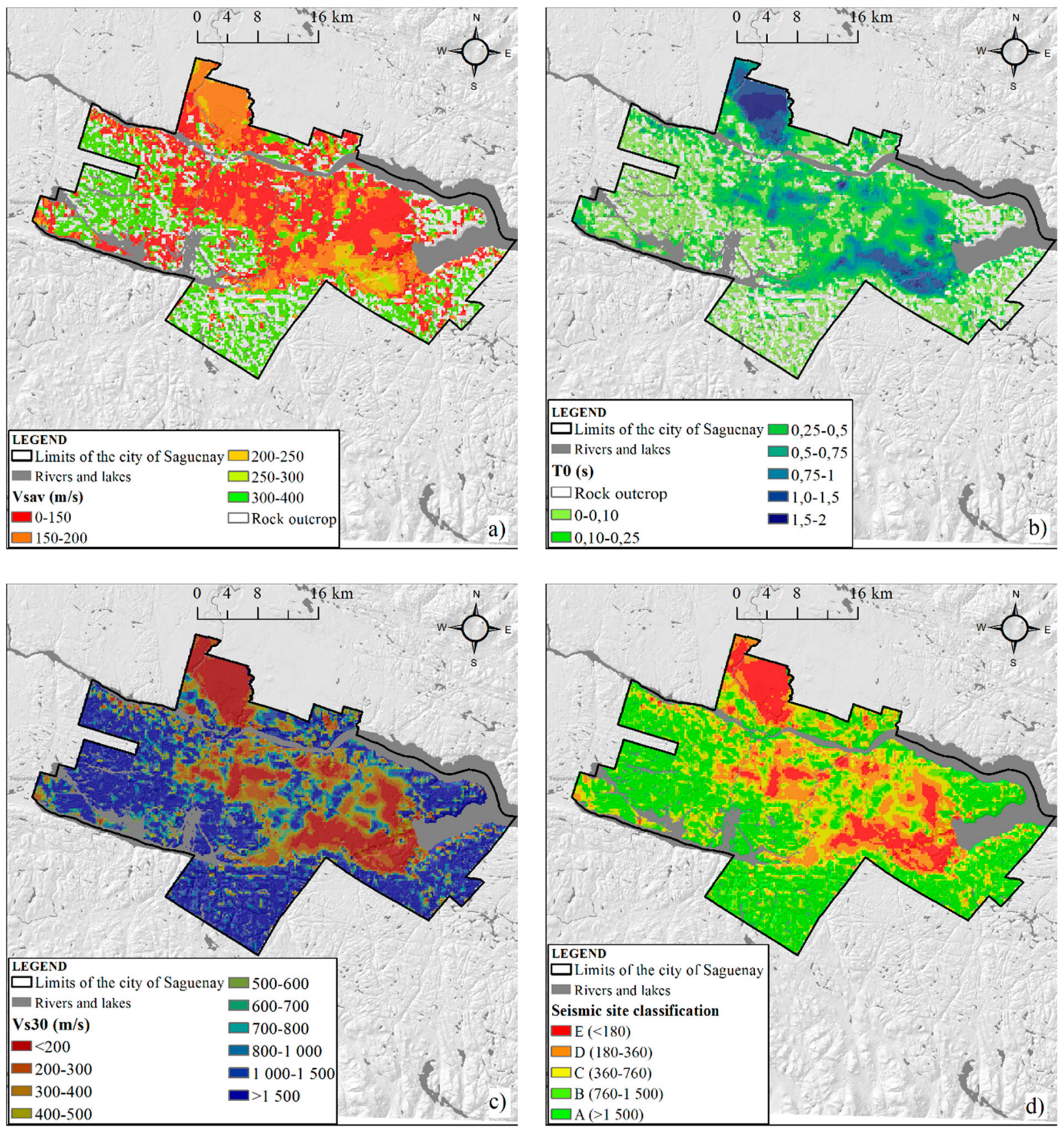

Figure 8. Spatial distribution maps of (a) $V_{\text {savi }}$ (b) $T_{0} ;$ (c) $V_{\mathrm{s} 30}$ and (d) seismic soil classes according to the NBCC 2015 classification.

the bedrock. The use of penetration test data to determine $V_{\mathrm{s}}$ may introduce high uncertainties. It is acknowledged that the absence of direct in situ $V_{\mathrm{s}}$ measurements does represent a weaker aspect of this study. Such data would be of great value for cross-checking the $V_{\mathrm{s}}$ profiles produced herein. More appropriate methods of determination of the $V_{\mathrm{s}}$ must be implemented for the sand layer to assess whether the discrepancies of $V_{s}$ values between this study and that of Nastev et al. (2016b) are a result of particular field conditions or inappropriate methods of investigation. The representativeness of $V_{s}$ values for the till layer and the bedrock would be improved by actual field data of this parameter from these geological units. Finally, the cell size of the raster was chosen based on expert opinion, where the cell size of $250 \mathrm{~m}$ is considered as being sufficient to capture the lateral and vertical variations of the considered model units.

The spatial distributions were defined according to a rigorous approach combining geological interpretations and a reliable database of geological surveys and results from multiple penetration tests. This approach results in a 3D geological model that accurately represents the complex stratigraphy found across the Saguenay territory. This representativeness contributes to the good 
resolution of the developed maps of spatial distribution of $V_{\mathrm{s} 30}$ and $T_{0}$. Assessing the spatial distribution of both $V_{\mathrm{s} 30}$ and $T_{0}$ across the Saguenay territory provides a better understanding of the potential seismic site effects than producing solely a spatial distribution of $V_{\mathrm{s} 30}$. The spatial distribution of the seismic soil classes (Figure 8 (d)) shows that numerous sectors with $\mathrm{E}$ and $\mathrm{D}$ soil classes are present in the populated lowland sectors of the Saguenay region (Chicoutimi, Jonquière, La Baie and the Shipshaw areas). These sectors therefore merit particular attention from the City of Saguenay as these are sectors having a potentially high seismic amplification induced by the presence of a thick clay layer. Conversely, the Saguenay highlands characterised by a thin discontinuous till layer and rock outcrops are mainly of A and B soil classes that are less susceptible to seismic amplification.

The spatial distributions of $V_{\mathrm{s} 30}$ and $T_{0}$ that were achieved in this study provide a useful assessment of the sectors that are the most sensitive to seismic site effects in the Saguenay territory. They also incorporate the current understanding and the available geotechnical data related to the deposits of the study area. The spatial distribution of $V_{\mathrm{s}}, V_{\mathrm{s} 30}$ and $T_{0}$ presented in this paper constitute an important first step for the development of ground motion maps for typical seismic scenarios. These maps are currently being prepared for use in a seismic risk analysis of buildings in the study area.

\section{Acknowledgements}

The authors are grateful to the team of the PACES project at UQAC for providing access to the database and, particularly, to Julien Walter for useful discussions and precious help in the development of the $3 \mathrm{D}$ geological model.

\section{Disclosure statement}

No potential conflict of interest was reported by the authors.

\section{Funding}

The authors thank the Geological Survey of Canada, the City of Saguenay, the Natural Sciences and Engineering Research Council of Canada and the Fondation de l'UQAC for financial support for this study.

\section{References}

ARANZ Geo Limited. 2014. User Manual for Leapfrog Geo Version 2.1. Christchurch: ARANZ Geo Limited.

Bard, P.-Y., M. Campillo, F. J. Chávez-Garcia, and F. SánchezSesma. 1988. "The Mexico Earthquake of September 19, 1985 - A Theoretical Investigation of Large- and Small- scale Amplification Effects in the Mexico City Valley." Earthquake Spectra 4 (3): 609-633.

Benjumea, B., J. A. Hunter, S. E. Pullan, G. R. Brooks, M. Pyne, and J. M. Aylsworth. 2008. "Vs30 and Fundamental Site Period Estimates in Soft Sediments of the Ottawa Valley from Near-surface Geophysical Measurements." Journal of Environmental \& Engineering Geophysics 13 (4): 313-323. doi:10.2113/JEEG13.4.313.

Boore, D. M. 2003. "Simulation of Ground Motion Using the Stochastic Method.” Pure and Applied Geophysics 160 (34): 635-676. doi:10.1007/PL00012553.

Borcherdt, R. D. 1994. "Estimates of Site-dependent Response Spectra for Design Methodology and Justification." Earthquake Spectra 10: 617-653.

Bouchard, R., D. J. Dion, and F. Tavenas. 1983. "Origine de la préconsolidation des argiles du Saguenay, Québec." Canadian Geotechnical Journal 20: 315-328.

Braganza, S., G. M. Atkinson, H. Ghofrani, B. Hassani, L. Chouinard, P. Rosset, D. Motazedian, and J. Hunter. 2016. "Modeling Site Amplification in Eastern Canada on a Regional Scale.” Seismological Research Letters 87 (4): 1008-1021. doi:10.1785/0220160009.

Castellaro, S., F. Mulargia, and P. L. Rossi. 2008. "Vs30: Proxy for Seismic Amplification?" Seismological Research Letters 79 (4): 540-543.

CEN (European Committee for Standardisation). 2004. Eurocode 8: Design of Structures for Earthquake Resistance, Part 1: General Rules, Seismic Actions and Rules for Buildings. EN 1998-1:2004. Brussels.

CERM-PACES. 2013. Résultat du programme d'acquisition de connaissances sur les eaux souterraines de la région Saguenay-Lac-Saint-Jean. Chicoutimi: Centre d'études sur les ressources minérales, Université du Québec à Chicoutimi.

Chesnaux, R., M. Lambert, J. Walter, V. Dugrain, A. Rouleau, and R. Daigneault. 2017. "A Simplified Geographical Information System (GIS)-based Methodology for Modeling the Topography of Bedrock: Illustration Using the Canadian Shield." Applied Geomatics 9 (1): 61-78. doi:10.1007/s12518-017-0183-1.

Chesnaux, R., M. Lambert, J. Walter, U. Fillastre, M. Hay, A. Rouleau, R. Daigneault, A. Moisan, and D. Germaneau. 2011. "Building a Geodatabase for Mapping Hydrogeological Features and 3D Modeling of Groundwater Systems: Application to the Saguenay-LacSt.-Jean Region, Canada." Computers and Geosciences 37 (11): 1870-1882. doi:10.1016/j.cageo.2011.04.013.

Daigneault, R. A., P. A. Cousineau, E. Leduc, G. Beaudoin, S. Milette, N. Horth, D. W. Roy, M. Lamothe, and G. Allard. 2011 ?. Cartographie des formations superficielles réalisée dans le territoire municipalité du Saguenay-Lac-Saint-Jean (Québec) entre 2009 et 2011. Final Report of CERM to the Ministère des Ressources Naturelles GM 65970.

Davidson, A. 1998. Geological Map of the Grenville Province?: Canada and Adjacent Parts of the United States of America. Map 1947A. Québec: Geological Survey of Canada.

Dion, D. J. 1986. Levé géotechnique de la région de JonquièreChicoutimi-La Baie. Québec: Direction générale de l'exploration géologique et minérale, Ministère de l'énergie et des ressources, MB 86-51. 136

Dobry, R., and M. Vucetic. 1987. "Dynamic Properties and Seismic Response of Soft Clay Deposits." In The 
International Symposium on Geotechnical Engineering of Soft Soils, 51-87. Mexico City.

Finn, W. D. L., and A. Wightman. 2004. "Erratum: Ground Motion Amplification Factors for the Proposed 2005 Edition of the National Building Code of Canada." Canadian Journal of Civil Engineering 31 (4): 718-718. doi:10.1139/104-069.

Ghofrani, H., G. M. Atkinson, and K. Goda. 2013. "Implications of the 2011 M9.0 Tohoku Japan Earthquake for the Treatment of Site Effects in Large Earthquakes." Bulletin of Earthquake Engineering 11 (1): 171-203. doi:10.1007/s10518-012-9413-4.

Hébert, C., and P. Lacoste. 1998. Géologie de la région de Jonquière-Chicoutimi (SNRC 22D/06). Québec: Bibliothèque nationale du Québec. Géologie Québec24.

Hegazy, Y. A., and P. W. Mayne. 1995. "Statistical Correlations Between vs and Cone Penetration Data for Different Soil Types." In International Symposium on Cone Penetration Testing, CPT '95, 173-178. Linkoping.

Hunter, J. A., H. L. Crow, G. R. Brooks, M. Pyne, D. Motazedian, M. Lamontagne, A. J.-M. Pugin, et al. 2010. Seismic Site Classification and Site Period Mapping in the Ottawa Area Using Geophysical Methods. Open File 6273. 1 DVD. Geological Survey of Canada.

ICC (International Code Council). 2012. International Building Code. International Code Council.

IRCC (Institut de Recherche en Construction au Canada). 2015. Code national du bâtiment - Canada 2015. 14th ed. Ottawa: Commission canadienne des codes du bâtiment et de prévention des incendies - Conseil national de recherches du Canada.

Joyner, W. B., R. E. Warrick, and T. E. Fumal. 1981. "The Effect of Quaternary Alluvium on Strong Ground Motion in the Coyote Lake, California, Earthquake of 1979." Bulletin of the Seismological Society of America 71: 13331349.

Kramer, S. L. 1995. Geotechnical Earthquake Engineering. Washington, NJ: Prentice Hall.

Lasalle, P., and G. Tremblay. 1978. Dépôts meubles $d u$ Saguenay-Lac-Saint-Jean. Québec: Direction générale de la recherche géologique et minérale, Ministère des Ressources Naturelles.

Leboeuf, D., D. Perret, M.-J. Nollet, L. Lamarche, M. Nastev, and M. Parent. 2013. Microzonage sismique des villes de Québec-Ancienne-Lorette et réserve indienne Wendake (catégories d'emplacement). Québec: Commission géologique du Canada. Dossier public Québec.
Maugeri, M., and C. Soccodato, eds. 2014. Earthquake Geotechnical Engineering Design. Geotechnical, Geological and Earthquake Engineering. Berlin: Springer.

Mayne, P. W., and G. J. Rix. 1995. "Correlations Between Shear-wave Velocity and Cone Tip Resistance in Natural Clays." Japanese Society of Soil Mechanics and Foundation Engineering 35 (2): 107-110.

MERN. 2017. Base de données topographiques du Québec. BDTQ 20k. Scale 1/20 000. Ministère des Energies et Ressources Naturelles. http://geoboutique.mern.gouv.qc.ca.

Motazedian, D., and J. Hunter. 2008. "Development of an NEHRP Map for the Orleans Suburb of Ottawa, Ontario." Canadian Geotechnical Journal 45 (8): 1180-1188. doi:10. 1139/T08-051.

Nastev, M., M. Parent, N. Benoit, M. Ross, and D. Howlett. 2016a. "Regional Vs30 Model for the St. Lawrence Lowlands, Eastern Canada." Georisk 10 (3): 0-13. doi:10. 1080/17499518.2016.1149869.

Nastev, M., M. Parent, M. Ross, D. Howlett, and N. Benoit. 2016b. "Geospatial Modelling of Shear-wave Velocity and Fundamental Site Period of Quaternary Marine and Glacial Sediments in the Ottawa and St. Lawrence Valleys, Canada." Soil Dynamics and Earthquake Engineering 85 (3): 103-116.

Ohta, Y., and N. Goto. 1978. "Empirical Shear-wave Velocity Equations in Terms of Characteristic Soil Indexes." Earthquake Engineering Structural Dynamics 6: 167-187.

Paradis, S. J., M. Parent, D. Perret, and C. Gegin. 1998. Géologie des formations superficielles, Saint-Fulgence et La Baie, Québec, document public 3710, carte avec notes marginales. Commission géologique du Canada.

Robertson, P. K. 2009. "Interpretation of Cone Penetration Tests - A Unified Approach.” Canadian Geotechnical Journal 46 (11): 1337-1355.

Rosset, P., M. Bour-Belvaux, and L. Chouinard. 2015. "Microzonation Models for Montreal with Respect to Vs30." Bulletin of Earthquake Engineering 13 (8): 22252239. doi:10.1007/s10518-014-9716-8.

Towhata, I. 2014. Geotechnical Earthquake Engineering. Berlin: Springer. doi:10.1007/ 978-3-540-35783-4.

Wair, B. R., J. T. DeJong, and T. Shantz. 2012. Guidelines for Estimation of Shear Wave Velocity Profiles. Report, 68. Pacific Earthquake Engineering Research Center.

Wills, C. J., and K. B. Clahan. 2006. "Developing a Map of Geologically Defined Site-condition Categories for California." Bulletin of the Seismological Society of America 96 (4A): 1483-1501. doi:10.1785/0120050179. 